\title{
Investigating the first-cycle irreversibility of lithium metal oxide cathodes for $\mathrm{Li}$ batteries
}

\author{
Sun-Ho Kang $\cdot$ Won-Sub Yoon $\cdot$ Kyung-Wan Nam • \\ Xiao-Qing Yang $\cdot$ Daniel P. Abraham
}

Received: 28 September 2007/ Accepted: 27 November 2007/Published online: 30 April 2008

(C) Springer Science+Business Media, LLC 2008

\begin{abstract}
Layered lithium metal oxide cathodes typically exhibit irreversibility during the first cycle in lithium cells when cycled in conventional voltage ranges (e.g., 3-4.3 V vs. $\left.\mathrm{Li}^{+} / \mathrm{Li}\right)$. In this work, we have studied the first-cycle irreversibility of lithium cells containing various layered cathode materials using galvanostatic cycling and in situ synchrotron X-ray diffraction. When cycled between 3.0 and $4.3 \mathrm{~V}$ vs. $\mathrm{Li}^{+} / \mathrm{Li}$, the cells containing $\mathrm{LiCoO}_{2}$, $\mathrm{LiNi}_{0.8} \mathrm{Co}_{0.15} \mathrm{Al}_{0.05} \mathrm{O}_{2}$, and $\mathrm{Li}_{1.048}\left(\mathrm{Ni}_{1 / 3} \mathrm{Co}_{1 / 3} \mathrm{Mn}_{1 / 3}\right)_{0.952} \mathrm{O}_{2}$ as cathodes showed initial coulombic efficiencies of 98.0, 87.0 , and $88.6 \%$, respectively, at relatively slow current $(8 \mathrm{~mA} / \mathrm{g})$. However, the "lost capacity" could be completely recovered by discharging the cells to low voltages $\left(<2 \mathrm{~V}\right.$ vs. $\left.\mathrm{Li}^{+} / \mathrm{Li}\right)$. During this deep discharge, the same cells exhibited voltage plateaus at $1.17,1.81$, and $1.47 \mathrm{~V}$, respectively, which is believed to be associated with formation of a $\mathrm{Li}_{2} \mathrm{MO}_{2}$-like phase $(\mathrm{M}=\mathrm{Ni}, \mathrm{Co}, \mathrm{Mn})$ on the oxide particle surface due to very sluggish lithium diffusion in $\mathrm{Li}_{\varepsilon} \mathrm{MO}_{2}$ with $\varepsilon \rightarrow 1$ (i.e., near the end of discharge).
\end{abstract}

The submitted manuscript has been created by UChicago Argonne, LLC, Operator of Argonne National Laboratory ("Argonne”).

Argonne, a U.S. Department of Energy Office of Science laboratory, is operated under Contract No. DE-AC02-06CH11357. The

U.S. Government retains for itself, and others acting on its behalf, a paid-up nonexclusive, irrevocable worldwide license in said article to reproduce, prepare derivative works, distribute copies to the public, and perform publicly and display publicly, by or on behalf of the Government.

S.-H. Kang $(\bowtie) \cdot$ D. P. Abraham

Chemical Sciences and Engineering Division, Argonne National

Laboratory, Argonne, IL 60439, USA

e-mail: sunho.kang@anl.gov

W.-S. Yoon · K.-W. Nam · X.-Q. Yang

Chemistry Department, Brookhaven National Laboratory,

Upton, NY 11973, USA
The voltage relaxation curve and in situ $\mathrm{X}$-ray diffraction patterns, obtained from a $\mathrm{Li} / \mathrm{Li}_{1.048}\left(\mathrm{Ni}_{1 / 3} \mathrm{Co}_{1 / 3} \mathrm{Mn}_{1 / 3}\right)_{0.952} \mathrm{O}_{2}$ cell, showed that the oxide cathode reversibly returned to its original state [i.e., $\mathrm{Li}_{1.048}\left(\mathrm{Ni}_{1 / 3} \mathrm{Co}_{1 / 3} \mathrm{Mn}_{1 / 3}\right)_{0.952} \mathrm{O}_{2}$ ] during relaxation following the deep discharge to achieve $100 \%$ cycle efficiency.

\section{Introduction}

Lithium metal oxides with either layered (e.g., $\mathrm{LiCoO}_{2}$ ) or spinel structure (e.g., $\mathrm{LiMn}_{2} \mathrm{O}_{4}$ ) are the most commonly used cathode materials in commercial lithium batteries. When cycled in cells with a lithium counter electrode, the lithium metal oxide cathodes typically exhibit irreversible capacity loss during the first cycle; lithium ions extracted from the oxide during initial charge are not fully re-inserted into the cathode, leading to loss of available capacity.

There have been several studies to identify the origin of the first-cycle irreversibility of layered cathode materials [16]. Arai et al. [1] attributed the irreversibility of $\mathrm{LiNiO}_{2}$ to formation of inactive (electrically isolated) domains in the cathode structure at high degrees of delithiation $(y>0.8)$ of $\mathrm{Li}_{1-y} \mathrm{NiO}_{2}$. Zhang et al. [2] reported that formation of a solid-electrolyte interphase on the cathode surface was responsible for the irreversible capacity loss of lithium nickel mixed oxide. Choi and Manthiram [6] correlated the irreversible capacity loss of $\mathrm{Li}\left(\mathrm{Ni}_{1 / 3} \mathrm{Co}_{1 / 3} \mathrm{Mn}_{1 / 3}\right) \mathrm{O}_{2}$ to the surface area of the oxide powder and attributed the capacity loss to a parasitic electrochemical reaction occurring on the oxide particle surface. Delmas et al. [3,4] attributed the lack of reversibility of $\mathrm{Li} / \mathrm{Li}_{1-z} \mathrm{Ni}_{1-z} \mathrm{O}_{2}$ cells to a local collapse of the interslab space due to the oxidation of nickel ions in the lithium layers (i.e., $\mathrm{Ni}_{\mathrm{Li}}^{2+} \rightarrow \mathrm{Ni}_{\mathrm{Li}}^{3+}$ ) during the first charge. 
They explained that the vacant lithium sites around such extra, trivalent nickel ions were unlikely to be re-lithiated unless the re-lithiation process was performed at a very low rate and potential with concurrent structural damages to the cathode structure [3, 4]. On the other hand, Mueller-Neuhaus et al. [5] claimed that the term "irreversible capacity" of $\mathrm{Li}_{x} \mathrm{Ni}_{1-y} \mathrm{Fe}_{y} \mathrm{O}_{2}$ is simply a misnomer; they showed that the sudden potential drop during discharge of a $\mathrm{Li} / \mathrm{Li}_{x} \mathrm{Ni}_{1-y} \mathrm{Fe}_{y} \mathrm{O}_{2}$ cell is due to a sudden decrease in lithiumion mobility in the intercalation host, and therefore, the lost capacity could be fully recovered by using extremely slow discharge current or by discharging the cell to low voltages (e.g., $<2 \mathrm{~V}$ vs. $\mathrm{Li}^{+} / \mathrm{Li}$ ) [5].

In this work, we have studied various layered lithium metal oxide cathode materials-including $\mathrm{LiCoO}_{2}$ (LCO), $\mathrm{LiNi}_{0.8} \mathrm{Co}_{0.15} \mathrm{Al}_{0.05} \mathrm{O}_{2}$ (LNCAO), and $\mathrm{Li}_{1.048}\left(\mathrm{Ni}_{1 / 3} \mathrm{Co}_{1 / 3}\right.$ $\left.\mathrm{Mn}_{1 / 3}\right)_{0.952} \mathrm{O}_{2}$ (LNCMO)—by galvanostatic cycling and in situ synchrotron X-ray diffraction (XRD). The origin of the first-cycle irreversibility of the cathode materials and resulting capacity loss observed in lithium cells are discussed based on the experimental observation.

\section{Experimental}

Cathode active materials studied in this work were LCO (Seimi, Japan), LNCAO (Fuji, Japan), and LNCMO (Seimi, Japan). The positive electrodes consisted of $84 \mathrm{wt} \%$ cathode active material, $8 \mathrm{wt} \%$ carbon, and $8 \mathrm{wt} \%$ polyvinylidene difluoride ( $\mathrm{PVdF}$ ) on aluminum foil. The LCO electrode was made in-house at Argonne National Laboratory, whereas the LNCAO and LNCMO electrodes were made by battery manufacturers Quallion LLC (Sylmar, CA) and Enerland Co., Ltd. (Gyeonggi-Do, South Korea), respectively. The anode was metallic lithium (FMC, USA). The electrolyte was $1.2 \mathrm{M} \mathrm{LiPF}_{6}$ in a 3:7 mixture (by weight) of ethylene carbonate and ethylmethyl carbonate (Tomiyama, Japan); the separator was a polypropylene-polyethylene-polypropylene tri-layer membrane (Celgard 2325). All electrochemical tests were conducted with 2032-type coin cells at room temperature.

In situ XRD spectra were collected on beam line X18A at the National Synchrotron Light Source (NSLS) at Brookhaven National Laboratory, using a wide-angle position-sensitive detector (PSD). The in situ XRD cell with Mylar windows has been described in detail elsewhere [7]. The wavelength used was $0.9999 \AA$ A. The PSD can collect one XRD scan up to $90^{\circ}$ of two theta angles within a few minutes with a good signal-to-noise ratio. It significantly reduces the data collection time for each scan, which allows us to study phase transitions in real time. The two theta angles of all XRD spectra presented in this paper have been converted to corresponding angles for $\lambda=1.54 \AA$, which is the wavelength of a conventional X-ray tube source with $\mathrm{Cu}-\mathrm{K} \alpha$ radiation, for easy comparison with other published results.

\section{Results and discussion}

Figure 1 shows the first charge/discharge profiles of lithium cells containing the LCO, LNCAO, and LNCMO cathodes between 2.8 and $4.3 \mathrm{~V}$ vs. $\mathrm{Li}^{+} / \mathrm{Li}$ at a current density of $8 \mathrm{~mA} / \mathrm{g}$. A very high first-cycle coulombic efficiency (CE1) is observed for the LCO cell (98.0\%), whereas the LNCAO and LNCMO cells exhibit lower efficiencies ( 87.0 and $88.6 \%$, respectively).

As discussed earlier, previous studies by Arai et al. [1] and Choi and Manthiram [6] on $\mathrm{LiNiO}_{2}$ and $\mathrm{LiNi}_{1 / 3} \mathrm{Co}_{1 / 3}$ $\mathrm{Mn}_{1 / 3} \mathrm{O}_{2}$, respectively, have indicated that initial irreversible capacity loss of lithium cells containing those oxide cathodes occurs mostly at high voltages. To examine

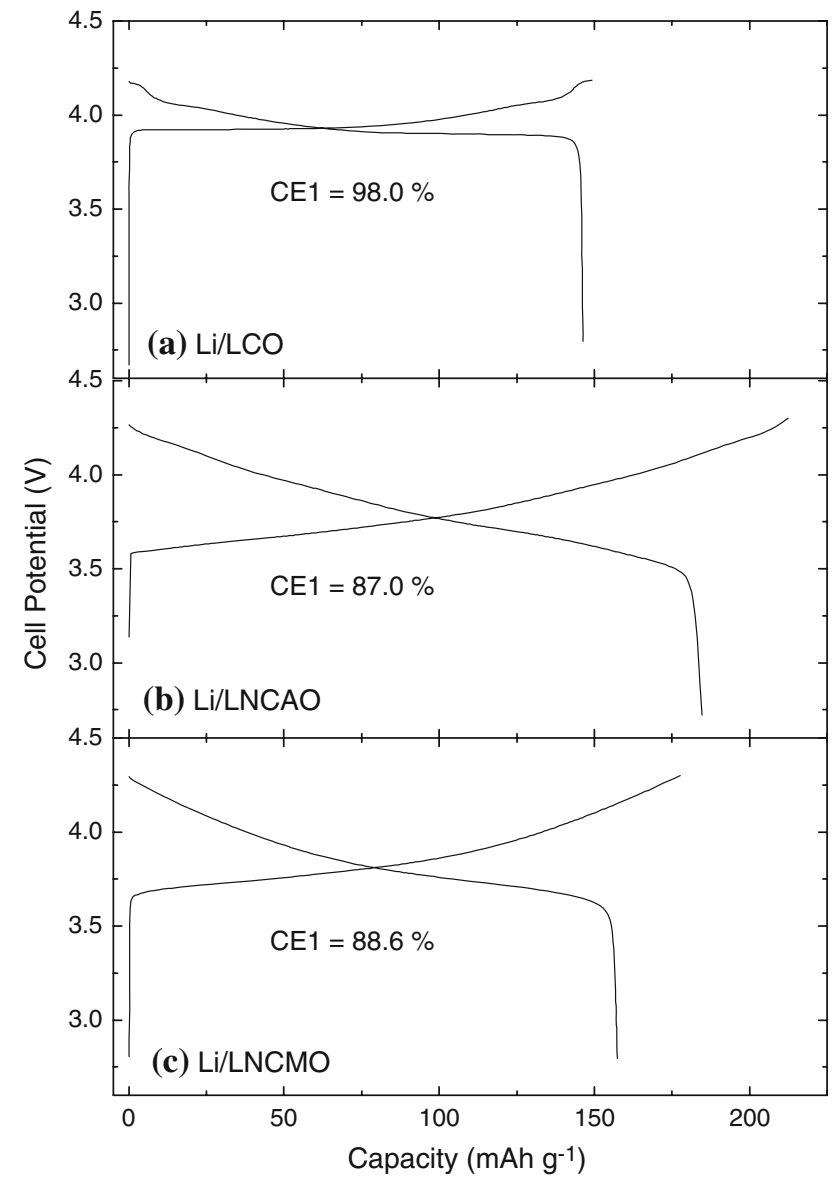

Fig. 1 Initial charge/discharge voltage profiles of lithium cells containing various cathodes between 2.8 and $4.3 \mathrm{~V}$ vs. $\mathrm{Li}^{+} / \mathrm{Li}$ at $8 \mathrm{~mA} / \mathrm{g}$ : (a) $\mathrm{LiCoO}_{2}$ (LCO), (b) $\mathrm{LiNi}_{0.8} \mathrm{Co}_{0.15} \mathrm{Al}_{0.05} \mathrm{O}_{2}$ (LNCAO), and (c) $\mathrm{Li}_{1.048}\left(\mathrm{Ni}_{1 / 3} \mathrm{Co}_{1 / 3} \mathrm{Mn}_{1 / 3}\right)_{0.952} \mathrm{O}_{2}$ (LNCMO). CE1 denotes the firstcycle coulombic efficiency 


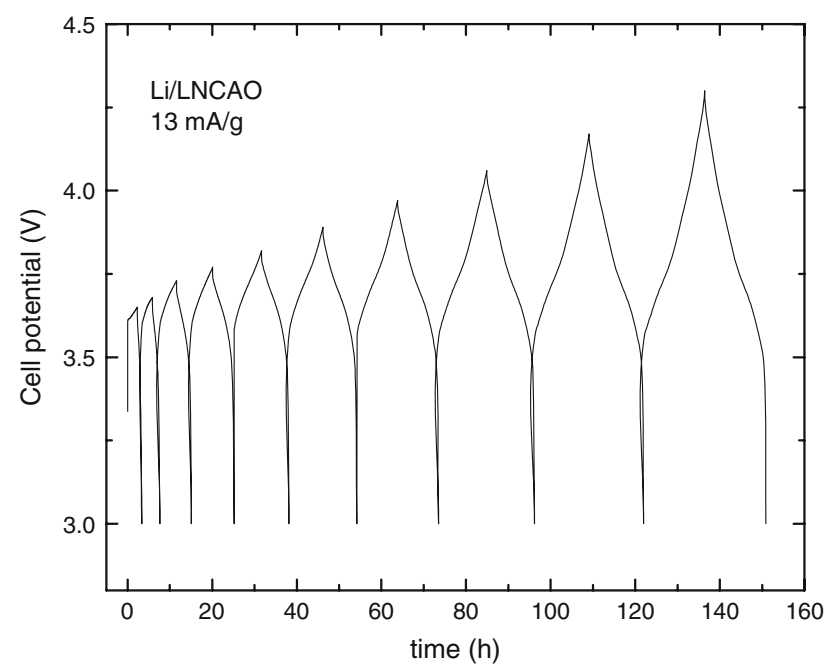

Fig. 2 Charge/discharge profiles of a $\mathrm{Li} / \mathrm{LNCAO}$ cell cycled by gradually increasing the upper cutoff voltage (from 3.65 to $4.3 \mathrm{~V}$ ). The lower cutoff voltage was fixed at $3.0 \mathrm{~V}$ and the cycling current density was $13 \mathrm{~mA} / \mathrm{g}$

voltage ranges most responsible for the initial capacity loss of the LCO, LNCAO, and LNCMO cells, we performed cycling experiments on these cells by gradually increasing the upper cutoff voltage. For example, a LNCAO cell was initially charged only to $3.65 \mathrm{~V}$ and discharged to $3.0 \mathrm{~V}$; the cell was then subsequently charged to $3.68 \mathrm{~V}$ and discharged to $3.0 \mathrm{~V}$. In this manner, the charging voltage was gradually increased to $4.3 \mathrm{~V}$ while the lower cutoff voltage was fixed at $3.0 \mathrm{~V}$; the voltage profile of the LNCAO cell obtained from this experiment is shown in Fig. 2. Similar experiments were performed for LCO and LNCMO cells; the resulting capacity variations and cycling efficiencies as a function of upper cutoff voltage of the three cells are given in Fig. 3.

As highlighted by circles in Fig. 3, and as shown in the insets of Fig. 3, all the cells exhibited irreversibility only at low-voltage ranges. For example, the LNCMO cell showed only $38.4 \%$ cycling efficiency (or capacity loss of $19.8 \mathrm{mAh} / \mathrm{g}$ ) when initially cycled between 3 and $3.72 \mathrm{~V}$. During the subsequent cycling between 3.0 and $3.75 \mathrm{~V}$, the cycling efficiency increased to $88.5 \%$ (or capacity loss of $3.9 \mathrm{mAh} / \mathrm{g}$ ); the cell then exhibited almost $100 \%$ cycling efficiency throughout the rest of cycling as can be seen in the inset of Fig. 3c. The results in Fig. 3 indicate that the irreversibility of these three cells is not related to structural changes of the oxides induced by delithiation nor to side reactions on the cathode surface, both of which would occur more predominantly at higher voltages.

Figure 4 shows charge/discharge profiles during the first cycle of the three cells using a "capacity-limit" (not a conventional voltage-limit) cycling condition. For example, a LNCMO cell was charged to $180 \mathrm{mAh} / \mathrm{g}$ capacity
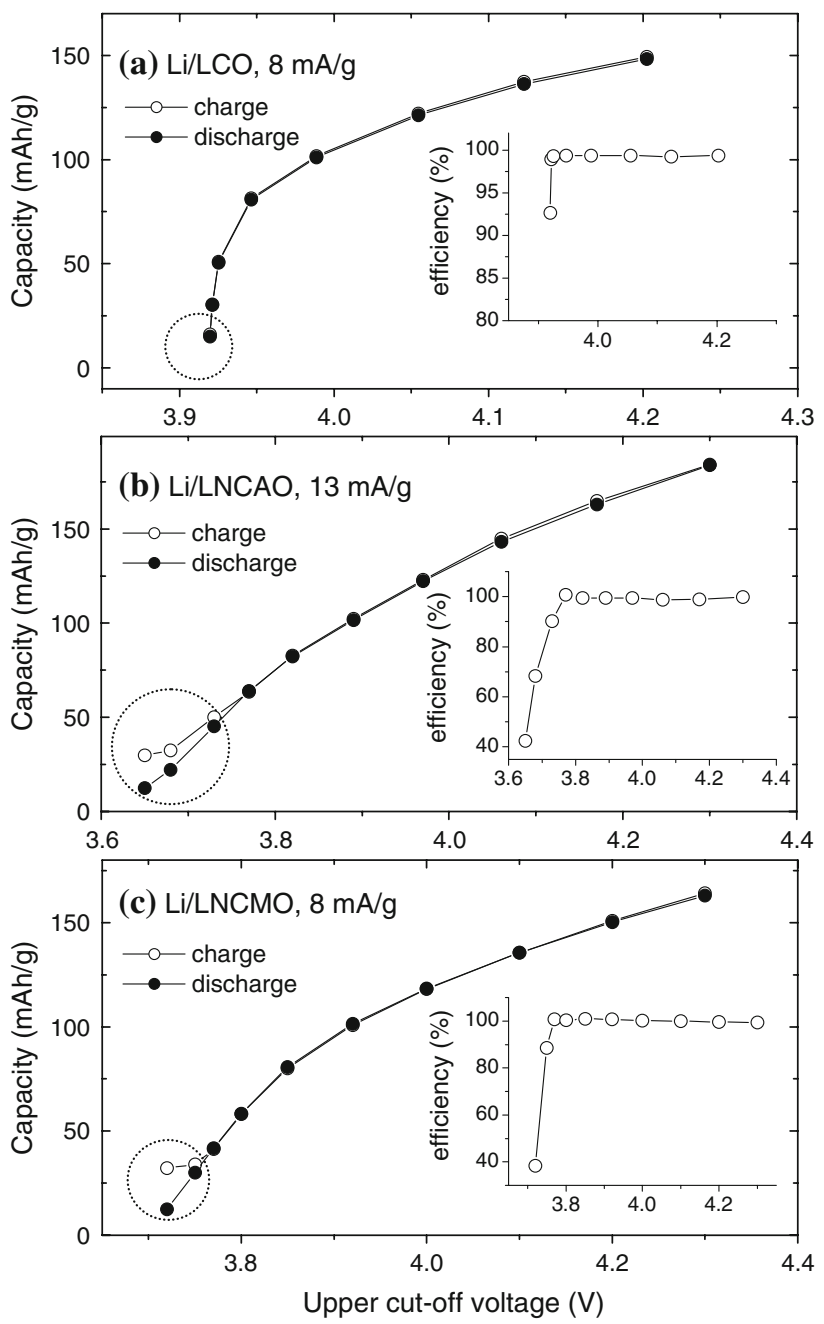

Fig. 3 Capacity variations of lithium cells as a function of upper cutoff voltage. The insets are cycling efficiency versus upper cutoff voltage plots

and then discharged to $180 \mathrm{mAh} / \mathrm{g}$ (i.e., $100 \%$ cycling efficiency), both at $8 \mathrm{~mA} / \mathrm{g}$. The three cells exhibited lowvoltage plateaus at 1.17 (LCO, see the inset of Fig. 4a), 1.81 (LNCAO), and $1.47 \mathrm{~V}$ (LNCMO) during discharge beyond the efficiencies shown in Fig. 1. The lost capacity during the initial cycle, observed when the cells were cycled between 3.0 and $4.3 \mathrm{~V}$ (Fig. 1), could be fully recovered by this deep discharge. These results are similar to those reported for $\mathrm{Li} / \mathrm{LiNi}_{0.95} \mathrm{Fe}_{0.05} \mathrm{O}_{2}$ cells by MuellerNeuhaus et al. [5]; those cells also showed low-voltage plateaus at $\sim 1.9 \mathrm{~V}$ vs. $\mathrm{Li}^{+} / \mathrm{Li}$ during deep discharge to achieve the $100 \%$ cycling efficiency.

The voltage and length of the plateaus observed during the deep discharge are current-density dependent. Figure 5 shows voltage profiles of a LNCMO cell (cell $A$ ) charged at a fixed charge current density $\left(i_{\mathrm{c}}\right)$ of $8 \mathrm{~mA} / \mathrm{g}$ and discharged to $100 \%$ efficiency at different discharge currents $\left(i_{\mathrm{d}}=2,4,8,16\right.$, and $32 \mathrm{~mA} / \mathrm{g}$ ). Note that no rest (or 


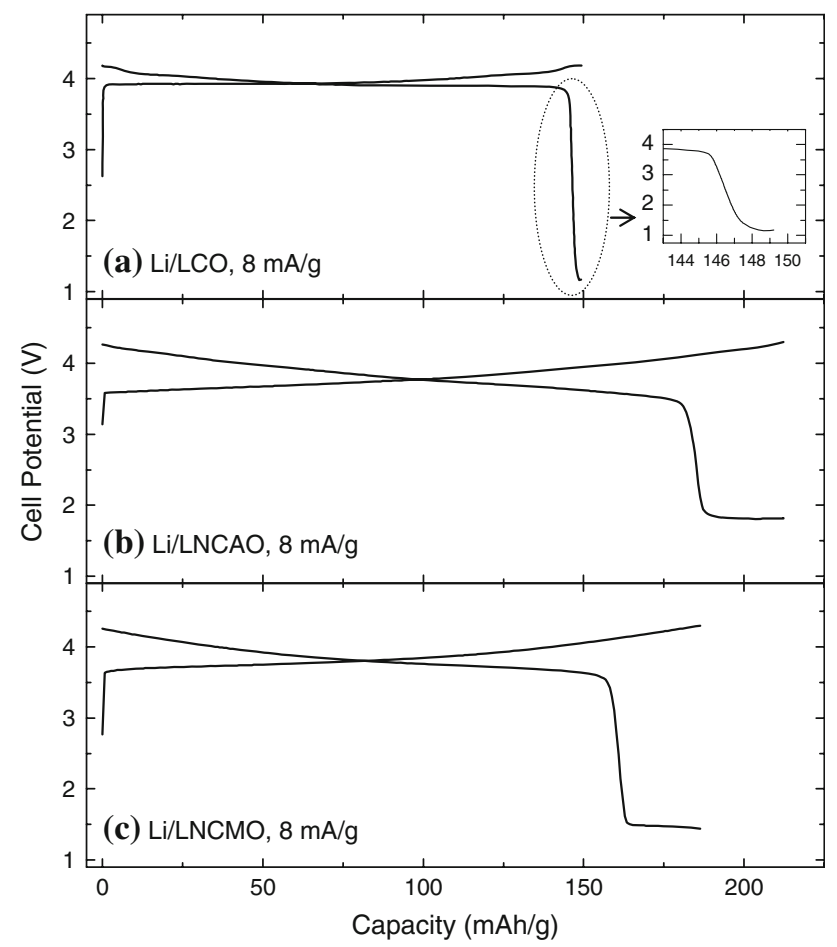

Fig. 4 Charge/discharge profiles during the first cycle of (a) Li/LCO, (b) $\mathrm{Li} / \mathrm{LNCAO}$, and (c) $\mathrm{Li} / \mathrm{LNCMO}$ cells cycled with $100 \%$ efficiency using a "capacity-limit" cycling condition

relaxation) time was given to the cell after each discharge process. As the discharge current rate increased, the cell showed longer low-voltage plateaus at lower voltages as highlighted with a circle in Fig. 5.

The low-voltage plateaus during deep discharge have been reported for lithium cells containing various layered lithium metal oxide cathodes [2, 5, 8, 9]. Neuhaus et al. [5]

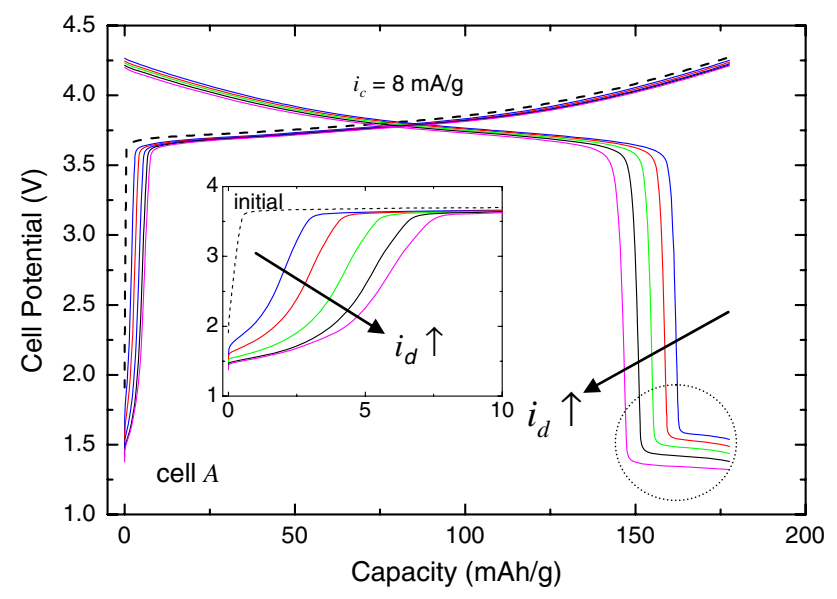

Fig. 5 Charge/discharge profiles of a Li/LNCMO cell (cell $A$ ) cycled with $100 \%$ efficiency using different discharge current $\left(i_{\mathrm{d}}=2,4,8\right.$, $16,32 \mathrm{~mA} / \mathrm{g})$. The charge current $\left(i_{\mathrm{c}}\right)$ was fixed at $8 \mathrm{~mA} / \mathrm{g}$. No rest time was given to the cell between discharge and subsequent charge processes have reported that a $\mathrm{Li} / \mathrm{LiNi}_{1-y} \mathrm{Fe}_{y} \mathrm{O}_{2}$ cell showed voltage plateaus at $\sim 1.9 \mathrm{~V}$ during deep discharge to achieve $100 \%$ cycling efficiency. Kang et al. [8] have reported that similar low-voltage plateaus were observed at $\sim 1.65 \mathrm{~V}$ in $\mathrm{Li} / \mathrm{Li}_{1+x}\left(\mathrm{Ni}_{0.5} \mathrm{Mn}_{0.5}\right)_{1-x} \mathrm{O}_{2}(0.05 \leq x \leq 0.15)$ cells during deep discharge. They related the low-voltage plateaus during deep discharge with very slow lithium diffusion in the lithium layers of the oxide structure [5, 8]. According to Van der Ven and Ceder's calculation and model [10], lithium-ion diffusion via "monovacancy hopping" becomes very slow due to a high activation energy barrier as the lithium content $(\varepsilon)$ approaches 1 in the layered $\mathrm{Li}_{\varepsilon} \mathrm{MO}_{2}$ (i.e., near the end of discharge). Due to the slow rate of lithium-ion diffusion in the layered structure compared to the lithium insertion rate during discharge, the lithium concentration increases significantly near the particle surface, which eventually induces formation of an overlithiated " $\mathrm{Li}_{2} \mathrm{MO}_{2}$ " $\left(\mathrm{Li}_{2} \mathrm{MO}_{2}\right.$ or $\mathrm{Li}_{2} \mathrm{MO}_{2}$-like) phase on the oxide particle surface $[5,8]$. The $\mathrm{Li}_{2} \mathrm{MO}_{2}$ phase has been observed for $\mathrm{M}=\mathrm{Ni}$ [11] and $\mathrm{M}=\mathrm{Ni}_{0.5} \mathrm{Mn}_{0.5}$ [12] from heavily overlithiated $\mathrm{LiNiO}_{2}$ and $\mathrm{LiNi}_{0.5} \mathrm{Mn}_{0.5} \mathrm{O}_{2}$, respectively, in lithium cells and for $\mathrm{M}=\mathrm{Mn}$ [13] by chemical lithiation of $\mathrm{LiMn}_{2} \mathrm{O}_{4}$ with $n$-butyl lithium. Therefore, the sudden voltage drop near the end of discharge (starting at $\sim 3.6 \mathrm{~V}$ in Fig. 5) and the low-voltage plateaus (at $1.25-1.5 \mathrm{~V}$ in Fig. 5) could be attributed to high lithium-ion concentration (i.e., high lithium chemical potential) and two-phase coexistence $\left(\mathrm{Li}_{\varepsilon} \mathrm{MO}_{2} /{ }^{\prime} \mathrm{Li}_{2} \mathrm{MO}_{2}\right.$ "), respectively, at the oxide particle surface.

The low-voltage plateaus are also observed during charge. However, as shown in the inset of Fig. 5, the lowvoltage plateaus are much shorter during charge than the corresponding ones during previous discharge. Note that the charge current rate $\left(i_{\mathrm{c}}\right)$ was fixed at $8 \mathrm{~mA} / \mathrm{g}$ for all charging processes.

As discussed above, the formation of an overlithiated " $\mathrm{Li}_{2} \mathrm{MO}_{2}$ " phase on the oxide particle surface is the result of kinetic limitations to lithium diffusion in the layered phase, not due to reasons associated with thermodynamic phase equilibrium. Therefore, lithium ions in the " $\mathrm{Li}_{2} \mathrm{MO}_{2}$ " phase also tend to diffuse into the layered phase of the oxide particle bulk to reach thermodynamic equilibrium. This re-equilibration process takes place together with the formation of the " $\mathrm{Li}_{2} \mathrm{MO}_{2}$ " phases along the lowvoltage plateau during discharge. Because the voltage plateaus at $\sim 2 \mathrm{~V}$ during charge are associated with lithium extraction from the surface " $\mathrm{Li}_{2} \mathrm{MO}_{2}$ " phase, the short low-voltage plateaus during charge may indicate that a significant portion of " $\mathrm{Li}_{2} \mathrm{MO}_{2}$ " phase disappears at the particle surface by the time the re-charge process starts. In this respect, one would expect that the lithium cell would not exhibit the low-voltage plateau during re-charge if enough (relaxation) time is given to the cell after the deep 


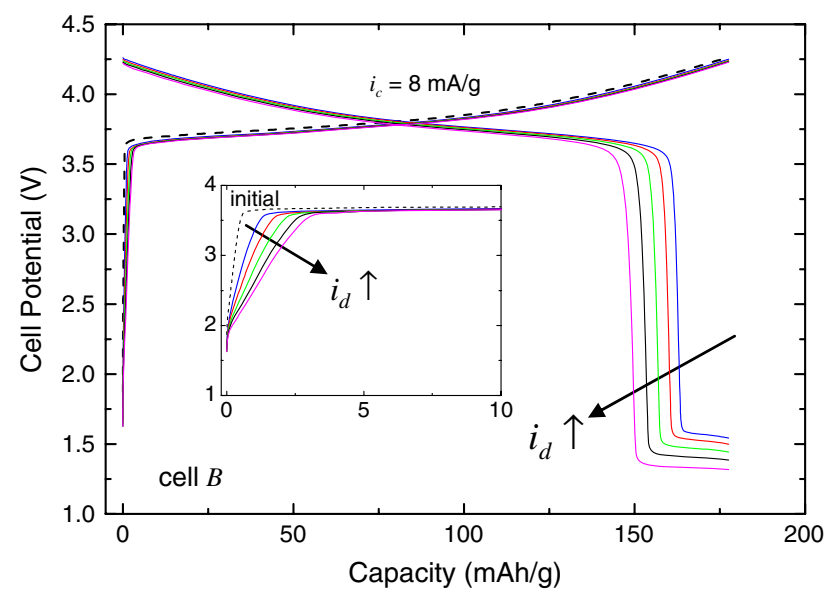

Fig. 6 Charge/discharge profiles of a Li/LNCMO cell (cell $B$ ) cycled with $100 \%$ efficiency using different discharge current $\left(i_{\mathrm{d}}=2,4,8\right.$, $16,32 \mathrm{~mA} / \mathrm{g})$. The charge current $\left(i_{\mathrm{c}}\right)$ was fixed at $8 \mathrm{~mA} / \mathrm{g}$ and a $6-\mathrm{h}$ rest time was given after each discharge

discharge. To confirm this, we constructed another LNCMO cell (cell $B$ ) and cycled it using the same protocol as in Fig. 5 except that a 6-h rest time (with zero current) was given to the cell after each discharge process. The results obtained from this experiment are shown in Fig. 6. Overall, the cycling profiles obtained from cell $B$ were very similar to those from cell $A$. However, no low-voltage plateaus at $\sim 2 \mathrm{~V}$ are observed during charge (see inset of Fig. 6). The data support our hypothesis that the overlithiated phase on the particle surface disappears during the 6$\mathrm{h}$ relaxation time by diffusion of lithium ions from the overlithiated phase into the Li-deficient layered phase (thermodynamic re-equilibration).

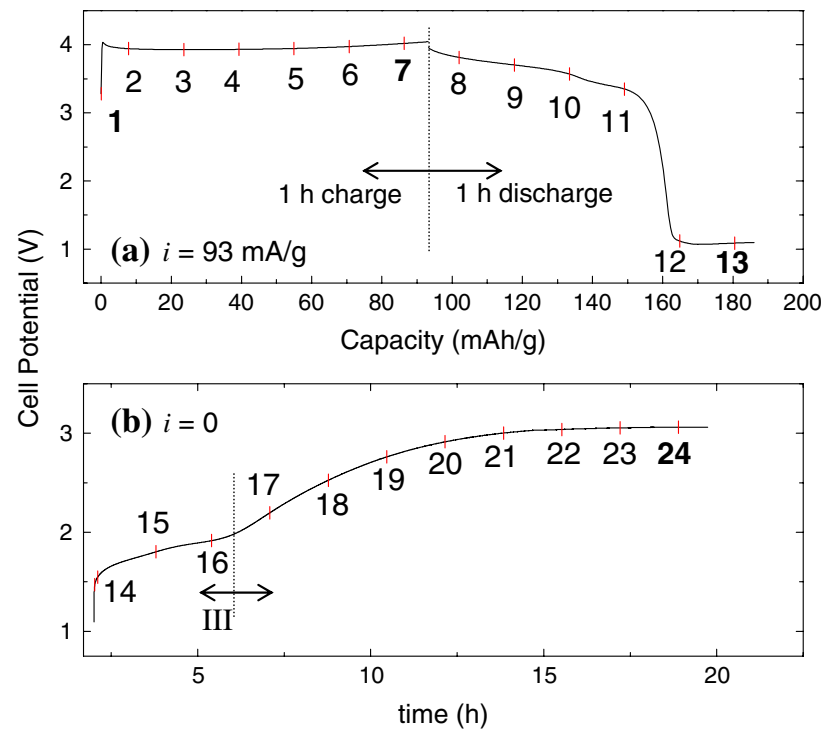

Fig. 7 (a) Charge/discharge profiles of a Li/LNCMO cell cycled with $100 \%$ efficiency at a current density of $93 \mathrm{~mA} / \mathrm{g}$. (b) Voltage relaxation curve of the cell after discharge to $100 \%$ efficiency
To examine whether (1) any irreversible structural change occurs during the low-voltage plateau and (2) the whole layered structure returns to its original state during the relaxation process as discussed above, we carried out an in situ synchrotron XRD experiment for a LNCMO cell. The cell was charged to $93 \mathrm{mAh} / \mathrm{g}$, corresponding to $\mathrm{Li}_{2 / 3} \mathrm{M}^{\prime} \mathrm{O}_{2}$ $\left(\mathrm{M}^{\prime}=\mathrm{Li}_{0.048}\left(\mathrm{Ni}_{1 / 3} \mathrm{Co}_{1 / 3} \mathrm{Mn}_{1 / 3}\right)_{0.952}\right)$ and discharged to $100 \%$ efficiency at a current rate of $93 \mathrm{~mA} / \mathrm{g}$ (i.e., $1-\mathrm{h}$ charge and discharge). Figure 7 a shows the voltage profile of the in situ cell. Since all the irreversibility in the LNCMO cell occurs only at the early state of charge (i.e., $<93 \mathrm{mAh} / \mathrm{g}$ ) as shown in Fig. 3c, the irreversible structural changes, if any, should be observed from the in situ XRD in this cycling range. After the cell was discharged to $100 \%$ efficiency, current was set to zero and the cell voltage change was monitored for $\sim 20 \mathrm{~h}$; the voltage curve during this
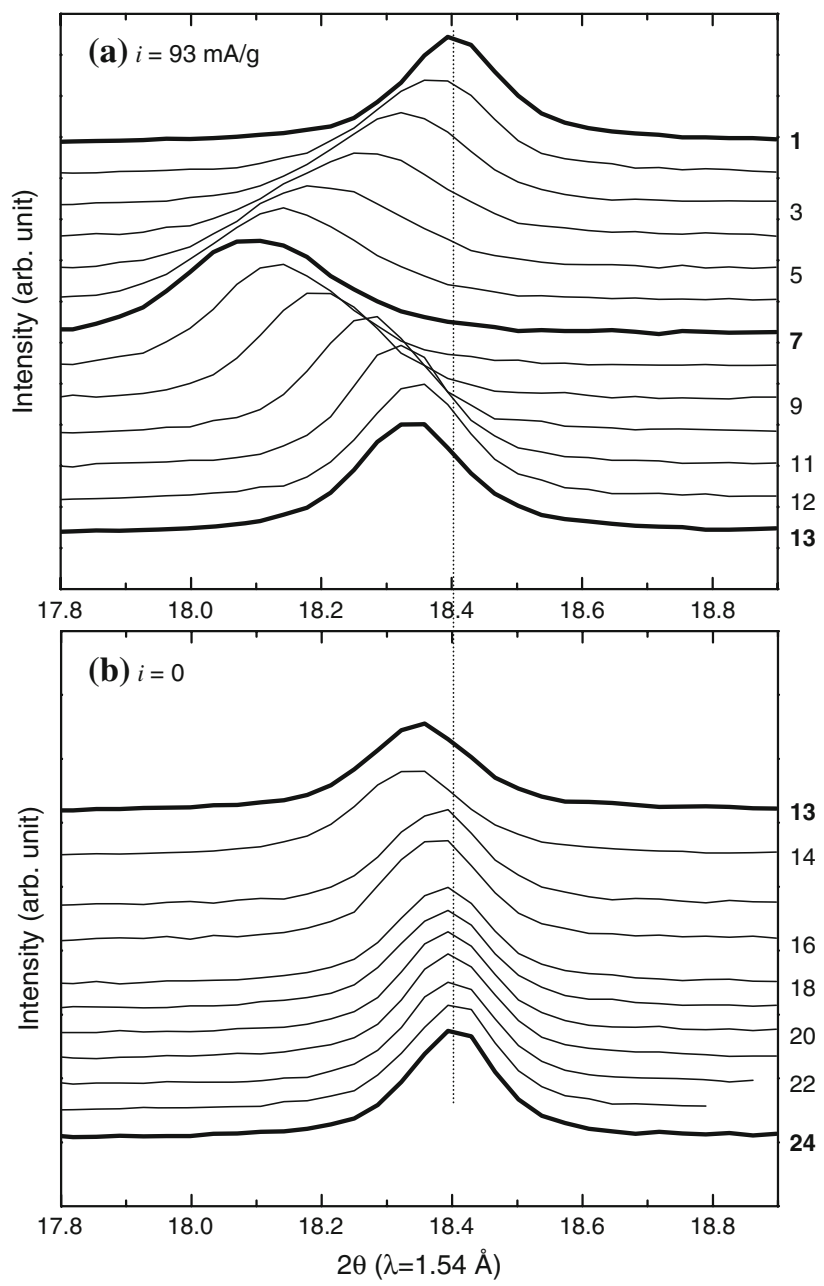

Fig. 8 In situ XRD patterns in the (003) Bragg reflection region of the $\mathrm{Li}_{1.048}\left(\mathrm{Ni}_{1 / 3} \mathrm{Co}_{1 / 3} \mathrm{Mn}_{1 / 3}\right)_{0.952} \mathrm{O}_{2}$ cathode during cycling (a) and relaxation (b) shown in Fig. 7. The $2 \theta$ angles have been converted to those corresponding to the $\mathrm{Cu} \mathrm{K} \alpha$ radiation $(\lambda=1.54 \AA)$. Scan numbers next to the diffraction patterns correspond to those along the charge/discharge profiles and relaxation curve in Fig. 7 
relaxation process is given in Fig. 7b. Changes in the oxide (003) Bragg reflection (indexed based on a hexagonal cell) during cycling and relaxation are shown in Fig. 8. Scan numbers next to the diffraction patterns in Fig. 8 correspond to those along the charge/discharge profiles and relaxation curve in Fig. 7.

During charge, the (003) peak moved continuously to a lower angle, indicating c-axis expansion upon delithiation. When the current was reversed (i.e., the cell was discharged), the (003) peak moved back to higher angle. Interestingly, the peak barely moved further during the low-voltage plateau and very early stage of the relaxation (scans 12-14 in Fig. 8a and b), which may be an indicator of two-phase coexistence along the low-voltage plateau. However, the overlithiated " $\mathrm{Li}_{2} \mathrm{MO}_{2}$ " phase, which has a space group of $\mathrm{P}-3 \mathrm{~m} 1$ and shows a (001) peak at $\sim 17^{\circ} 2 \theta_{\mathrm{CuK} \alpha}$ [11-13], was not detected in the diffraction patterns obtained in the low-voltage region (not shown), probably because the volumetric fraction of the " $\mathrm{Li}_{2} \mathrm{MO}_{2}$ " phase on the particle surface was below the XRD detection limit.

During relaxation, the open circuit voltage increased very slowly to $\sim 3 \mathrm{~V}$ vs. $\mathrm{Li}^{+} / \mathrm{Li}$ (Fig. $7 \mathrm{~b}$ ). At the same time, the (003) peak slowly moved to higher angle and eventually returned to its original position (see scans 1 and 24 in Fig. 8). It is noted that the whole relaxation process can be largely divided into two regimes with different time constants. We speculate that the early stage of the relaxation process (regime I) is associated with lithium diffusion across the " $\mathrm{Li}_{2} \mathrm{MO}_{2}$ " $/ \mathrm{Li}_{\varepsilon} \mathrm{MO}_{2}$ phase boundaries (i.e., phase transition), and the later stage (regime II) is associated with sluggish lithium diffusion in the $\mathrm{Li}_{\varepsilon} \mathrm{MO}_{2}$ phase.

\section{Summary}

In this work, we studied the first-cycle irreversibility of lithium cells containing $\mathrm{LiCoO}_{2}, \mathrm{LiNi}_{0.8} \mathrm{Co}_{0.15} \mathrm{Al}_{0.05} \mathrm{O}_{2}$, and $\mathrm{Li}_{1.048}\left(\mathrm{Ni}_{1 / 3} \mathrm{Co}_{1 / 3} \mathrm{Mn}_{1 / 3}\right)_{0.952} \mathrm{O}_{2}$ cathodes. When cycled between 3 and $4.3 \mathrm{~V}$ at $8 \mathrm{~mA} / \mathrm{g}$, those three cells exhibited first-cycle efficiencies of 98.0, 87.0, and $88.6 \%$, respectively. The lost capacity, however, could be fully recovered in a reversible way by deep-discharging the cells to low voltages
$(<2 \mathrm{~V})$. During the deep discharge, the cells showed lowvoltage plateaus, whose voltage and length depended on the discharge current density. For example, voltage plateaus were observed at $1.17\left(\mathrm{LiCoO}_{2}\right), 1.81\left(\mathrm{LiNi}_{0.8} \mathrm{Co}_{0.15} \mathrm{Al}_{0.05} \mathrm{O}_{2}\right)$, and $1.47 \mathrm{~V}\left(\mathrm{Li}_{1.048}\left(\mathrm{Ni}_{1 / 3} \mathrm{Co}_{1 / 3} \mathrm{Mn}_{1 / 3}\right)_{0.952} \mathrm{O}_{2}\right)$ at a discharge current density of $8 \mathrm{~mA} / \mathrm{g}$. The low-voltage plateaus have been attributed to the existence of a " $\mathrm{Li}_{2} \mathrm{MO}_{2}$ " phase on the oxide particle surface that forms because of kinetic limitations to lithium-ion diffusion in the $\mathrm{Li}_{\varepsilon} \mathrm{MO}_{2}$ structure $(\varepsilon \sim 1)$. An in situ synchrotron $\mathrm{X}$-ray diffraction study for $\mathrm{Li} / \mathrm{Li}_{1.048}$ $\left(\mathrm{Ni}_{1 / 3} \mathrm{Co}_{1 / 3} \mathrm{Mn}_{1 / 3}\right)_{0.952} \mathrm{O}_{2}$ cell showed an indication of a twophase coexistence at the low-voltage plateau and complete recovery of the layered structure during relaxation after deep discharge to $100 \%$ efficiency.

Acknowledgement This work was supported by the U.S. Department of Energy, Office of FreedomCar and Vehicle Technologies, under contract No. DE-AC02-06CH11357.

\section{References}

1. Arai H, Okada S, Sakurai Y, Yamaki J-I (1997) Solid State Ionics 95:275

2. Zhang SS, Xu K, Jow TR (2002) Electrochem Solid-State Lett 5:A92

3. Pérès JP, Delmas C, Rougier A, Broussely M, Perton F, Biensan P, Willmann P (1996) J Phys Chem Solids 57:1057

4. Delmas C, Pérès JP, Rougier A, Demourgues A, Weill F, Chadwick A, Broussely M, Perton F, Biensan Ph, Willmann P (1997) J Power Sources 68:120

5. Mueller-Neuhaus JR, Dunlap RA, Dahn JR (2000) J Electrochem Soc 147:3598

6. Choi J, Manthiram A (2005) Electrochem Solid-State Lett 8:C102

7. Balasubramanian M, Sun X, Yang XQ, McBreen J (2001) J Power Sources 92:1

8. Kang S-H, Park S-H, Johnson CS, Amine K (2007) J Electrochem Soc 154:A268

9. Todorov YM, Numata K (2004) Electrochim Acta 50:495

10. Van der Ven A, Ceder G (2001) J Power Sources 97-98:529

11. Dahn JR, Von Sacken U, Michal CA (1990) Solid State Ionics 44:87

12. Johnson CS, Kim J-S, Kropf AJ, Kahaian AJ, Vaughey JT, Fransson LML, Edström K, Thackeray MM (2003) Chem Mater $15: 2313$

13. David WIF, Goodenough JB, Thackeray MM, Thomas MGSR (1983) Rev Chem Miner 20:636 